\title{
Design and Implementation of Basic Department Operation Model
}

\author{
Nina Pavlovna Khodakova ${ }^{1 *}$, Elena Ivanovna Sukhova ${ }^{1}$, Irina E. Smirnova ${ }^{1}$, Nataliya \\ Ilyushina $^{1}$, and Tatyana Anatolievna Abdrashitova ${ }^{2}$ \\ ${ }^{1}$ Moscow City University, Institute of Pedagogy and Psychology of Education, Moscow, Russia \\ ${ }^{2}$ Eurasian Humanitarian Institute, Nur-Sultan, Kazakhstan
}

\begin{abstract}
. the article deals with an approach to designing and implementing the operation model for the basic department in the education quality control system at higher education institutions. The approach refers to university structure within the framework of network interaction between university and school employees. The authors describe the designed structure and main components of the operation model of the university basic department and list organizational and pedagogical conditions for the implementation of the basic department model at university. The authors give a brief description and characterize the components required in the process of establishing the interaction: content-related, managerial and resulting. Within the framework of the model, the authors provide a brief personal characteristic of the head of the basic department that is essential and determines the key direction for development.

The developed model has been implemented at the Institute of pedagogy and psychology of education of the State autonomous general education institution of higher education "Moscow City University" in cooperation with Moscow schools.
\end{abstract}

\section{Introduction}

The modern development of higher education in Russia is determined by goals set for society. The quality of education requires an updated organization of the educational process and its renewed structure. The emergence of basic departments at universities demonstrates the potential of their operation. However, currently, the model of such departments has not been sufficiently developed due to lacking work experience of the higher education institutions that have these departments. Basic departments can become an important component of network interaction that is relevant at the present stage of development of universities.

The emergence of departments at universities and the features of their operation have been the subject of the study for some Russian researchers. However, despite the amount of research dedicated to individual aspects of the problem, there is still no complex model of the basic department and the technology of its development and operation within the university structure. Moreover, there are no programs for the interaction between structural

* Corresponding author: HodakovaNP@mpgu.ru 
departments of universities with basic departments and the methodological recommendations for managing education quality at basic departments are limited.

In view of this, we have developed an approach to designing a basic department within the structure of the pedagogical university as part of network interaction between the university and the school, described the structure and main components of the basic department operation model at the pedagogical university and listed the organizational and pedagogical conditions for the implementation of the basic department interaction model at the university.

\section{Methods}

At present, a basic department is organized in the structure of a higher education institution and has material, methodological, human and information educational resources.

Material resources include the equipment fixed and available at the department space and classrooms: office equipment, computers, projectors, interactive desks and boards and any laboratory equipment, microscopes, measuring instruments.

Methodological resources encompass textbooks, teaching aids, reference books, dictionaries, lecture courses, methodological recommendations for students and teachers, curricula, funds of assessment means and materials for tests and examinations. These resources can be digital (digital educational courses, films and video lectures) or exist as hard copies.

Human resources refer to the faculty and support staff.

Information resources include federal portals, catalogs of digital textbooks and resources, social networks, communities, libraries, digital magazines and newspapers, distance learning systems, website builders, methodological materials, reference portals.

The following types of work are carried out at the department: methodological, educational and research work that includes individual work with students, the personal orientation of the educational process, improvement and activation of out-of-class work with students within research groups, improvement of the teachers' pedagogical and researchmethodological skills and the correction of components of main curricula, the competency matrix, the competency model, curricula and funds of assessment means, technological maps.

Network interaction is the interaction of different subjects that are united into a system. Such interaction ensures the simultaneous transmission of information between all subjects of the system.

In education, network interaction is defined primarily through the possibility of contact between participants of the educational process, while the contacts and the information exchange are available to all participants of the system.

During experimental work, the university department model based on schools was tested. The department included university staff and school representatives, students of Bachelor and Master's programs were assigned to the department.

We believe that the perfect model of a department is a competitive department that offers high-quality training for competitive skilled professionals.

Let us review the components of the developed model.

The organizational component includes organizational aspects that are objectively required in the process of creating interaction: preparation of regulations, orders, job descriptions, work schedules. The main goal of this component is to create an organizational environment for the interaction of the school and the university for the implementation of educational, methodological and research work [1-3].

The content-related component represents educational work that consists in the transfer of knowledge, the formation of the very essence of the educational process and network interaction which gives meaning and shapes network interaction. In this case, the 
organization of the educational process, during which the students' knowledge is formed, and the practice process, during which the acquired knowledge is transformed into skills, abilities and competencies [4-6].

The methodological component is the methodological foundation for the organization of the educational process, includes joint development of curricula, practical training plans, requirements for examinations, etc [7-9].

The managerial component acts as the leading element of the model. The component enables one to allocate the efforts most efficiently according to the goals and objectives of the organization. The main task of the component is to set goals for the system and its elements. In a way, the managerial component is systemically important.

It is important to see the difference between the work of a general manager and a department head. The general manager performs mainly administrative functions, realizes the managing function and the organizational aspect. The department head is mainly occupied with academic, research and methodological work.

The resulting component is the sum of the work of the entire system. The component summarizes the outcome and reviews the results of the system's efforts. The main goal of the component is to correct the system operation and monitor the results of the system's actions.

The proposed model can be used in the operation of any higher education institution to create a basic department within its structure [10-12].

An important part of the model's success is the employer's participation in modeling and carrying out the educational process at the university, development of the methodological framework and conducting research.

Within the framework of the presented model, the essential role is played by the department head who determines the key direction of its development. In this context, the head's personal qualities are of utmost importance. Social and psychological factors of the department head's work are critical in management. In essence, the development of these qualities determines the efficiency of management. The department head must take into account that the foundation of temperament is innate. Therefore, it is significantly harder to influence temperament than disposition. Temperament manifests primarily in emotional excitability, impressionability and impulsiveness. The department head must work hard on the employees' professional development, share knowledge and experience and teach the employees rational work techniques. This requires the head to develop pedagogical skills in the field of education.

\section{Results}

The operation of the basic department sufficiently corresponds to the education profile of the university and influences the performance of its functions as an educational institution. We have presented the role of the basic department in the university structure.

We developed the model of the university basic department based on the network form of interaction and identified the conditions for its implementation at universities.

We tested the management model for basic departments within the framework of network interaction at the university in cooperation with the school.

\section{Discussion}

For several years, studies were being conducted in Russia, in particular, at the Omsk State Pedagogical University, the basic department was viewed as a productive form of interaction between the research and pedagogical and student communities. This form was implemented at the university and ensured the integration of pedagogical science and practice. Within the 
framework of the work performed and based on obtained empirical data, problems were analyzed and risks and prospects of basic department operations were outlined. In the context of the conducted studies, the functions of the basic department were outlined and its operation was actualized in relation to the transformation of knowledge. The channels and means of transforming knowledge were analyzed and developed [13-15].

At the Russian state vocational-pedagogical university in Kemerovo, research was conducted that involved the determination of the project-target approach to managing methodological and research work of pedagogies at basic departments. The main types of methodological and research activities of basic department teachers were identified [16-18].

Industrial research chairs at universities can be considered foreign counterparts of basic departments. Industrial chairs organize students' learning and internships in companies, attract teachers from business and help companies find students for project work. The assessment of the efficiency of academic departments at the state university has become important due to the requirements of such state governing bodies as the executive and legislative power. State universities are increasingly being asked to report on the efficient use of dwindling financial resources of the state. Therefore, managers are responsible for ensuring that financial, human and physical resources of the university are allocated between academic departments in such a way that increases the institution's efficiency. To assess the efficiency of university academic departments, data envelopment analysis (DEA) is proposed. The method proposes a common efficiency indicator for every academic block. The method also defines the reasons for inefficiency in poorly performing departments and the changes that these departments must introduce to become more efficient. The method's usefulness as a planning tool is also discussed [19-21].

\section{Conclusion}

The presented model and the accumulated experience demonstrate the possibility of implementing basic departments at higher education facilities. In this case, considering the modern structure of education, the basic model can be seamlessly integrated into the general context of the Russian education system as a whole.

The main components of the basic department model are organizational, managerial, content-related, methodological and resulting. This basic set of elements reflects the possibility of creating a basic department and ensures its stable operation.

In practice, the proposed complex of elements can be significantly expanded and adapted to the specific environment of higher education institutions and the problems solved. The institution, in turn, entails the creation of an information environment between the participants, which requires simultaneous access to information for all members. The inclusion of the Internet as a new means of communication that ensures fast information exchange will make it possible to improve the operations of the basic department in the education quality control system at universities and in the training system for specialists, including those in the social field.

\section{References}

1. A.Yu Fedosov, N.P. Khodakova, Yu.A. Brevnova, A.A. Ziroyan, G.S. Sulyan, Amazonia Investiga 7(12), 579-584 (2018)

2. N.A. Bazaev, A.A. Danilov, A.Y. Gerasimenko, B.B Gorbunov, Y.P. Masloboev, D.A. Potapov, D.V Telyshev, S.A Tereshchenko, S.V. Selishchev, Biomedical Engineering 3(47), 111-115 (2013) 
3. J.A. Skurikhina, R.A. Valeeva, N.P Khodakova., E.V. Maystrovich, Eurasia Journal of Mathematics, Science and Technology Education 14(12), (2018)

4. A.J. Lekwa, L.A. Reddy, E.S. Shernoff, School Psychology Quarterly 34(1), 109-118 2018.

5. A.D. Miller, E.M. Ramirez, T.B. Murdock, Teaching and Teacher Education 64260 269 (2017)

6. B.S. Mitchell, R.G. Hirn, T.J. Lewis, Teacher Education and Special Education 40(2), 140-153 (2017)

7. P.M. Nelson, L.A. Reddy, C.M. Dudek, A.J. Lekwa, School Psychology Quarterly 32(4), 465-479 (2017)

8. M. Poulou, International Journal of School and Educational Psychology 5(2), 126-136 (2017)

9. L.A. Reddy, C.M. Dudek, A. Lekwa, Theory into Practice 56(1), 46-55 (2017)

10. N.P. Khodakova, N.A. Morozova, Personality Education 3, 39-45 (2016)

11. O.A. Lyubchenko, S.G. Vorovshchikov, The idea of the infrastructure project of the network interaction of educational organizations of general and higher education", In the collection: "Theory and practice of project management in education: horizons and risks", Materials of the international scientific-practical conference (2020)

12. V.V. Ryabov, O.A. Lyubchenko, S.G. Vorovshchikov, The network department of training counselors as a resource for networking between a children's camp and university, In the collection: "Management Solutions for Relevant Problems of Modern Education", Materials of the international round table (2019)

13. I.V. Fetter, Bulletin of the Orenburg State Pedagogical University. Electronic scientific journal 3(19), 213-221 (2016)

14. S. Clark, M. Newberry, Asia-Pacific Journal of Teacher Education 47(2), 1-16 (2018)

15. M.S. Poulou, L.A., Reddy, C.M. Dudek, School Psychology International 40(2) 25-48 (2019)

16. E.A. Shakuto, I.Yu. Kuznetsova, Economic and humanitarian studies of the regions 3, 85-89 (2019)

17. C.N.G. Chao, W.S.E. Chow, C. Forlin, F.C. Ho, Teaching and Teacher Education 66, 360-369 (2017)

18. C.M. Dudek, L.A. Reddy, A.L. Lekwa, Contemporary School Psychology 28 (2018)

19. A.A. Moreno, R. Tadepalli, Managerial \& Decision Economics 7(23), 385 (2002)

20. B. Niyivuga, A. Otara, D. Tuyishime. SAGE Open 9(1), (2019)

21. M. Cansiz, N. Cansiz, SAGE Open 9(4), (2019) 